\title{
Experimental, Clinical, and Morphological Analysis of H-Ras Oncoproteins for Locally Advanced Breast Cancer
}

\author{
A. M. Zhumakayeva ${ }^{1 *}$, K. D. Rakhimov ${ }^{2}$ I. M. Omarova ${ }^{3}$, S. M. Adekenov ${ }^{4}$, S. S. Zhumakayeva ${ }^{4}$ \\ ${ }^{1}$ Department of Oncology, Karaganda Medical University, Karaganda City, Kazakhstan, "International Research and Production \\ Holding Phytochemistry," Karaganda City, Republic of Kazakhstan; ${ }^{2}$ Department of Clinical Pharmacology, Doctor of Medical \\ Sciences, Kazakh National Medical University Named After S.D. Asfendiyarov, Researcher at "International Research and \\ Production Holding Phytochemistry," Karaganda City, Republic of Kazakhstan; ${ }^{3}$ Department of Oncology and Radiology, \\ Karaganda Medical University, Karaganda City, Republic of Kazakhstan; ${ }^{4}$ Doctor of Chemical Sciences, General Director of \\ "International Research and Production Holding Phytochemistry," Karaganda City, Republic of Kazakhstan
}

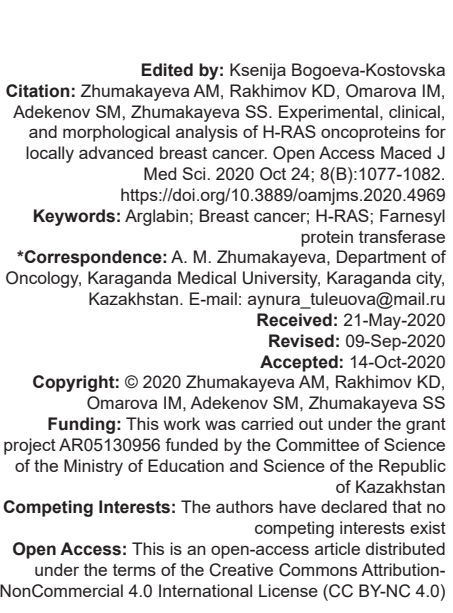

Abstract

BACKGROUND: Activated forms of RAS increase both in breast cancer and in cell lines in the presence of estimated glomerular filtration rate (EGFR) or HER2 expression. HRAS oncoproteins play an important role in enhancing the proliferation and resistance of breast cancer tumor cells to apoptosis. A number of studies have shown a significant decrease in EGFR expression after neoadjuvant chemotherapy, which has been clinical, manifested by an improvement in immediate efficacy and an increase in overall and relapse-free breast cancer survival rates.

AIM: The aim of the study was to study relapse-free survival depending on the expression of the H-RAS oncoprotein in patients with breast cancer who received different treatment regimens for the farnesyltransferase inhibitor.

METHODS: H-RAS status was assessed by immunohistochemistry.

RESULTS: A comparative analysis of patients with negative expression of $\mathrm{H}-\mathrm{RAS}$ oncoproteins showed a statistically significant increase in relapse-free survival in the subgroups who received neoadjuvant chemotherapy according to the $\mathrm{AC}$ regimen (adriablastin + cyclophosphamide) and AC + arglabin, compared with monotherapy by arglabin Kruskal-Wallis $=12.56$, where $p=0.001$. A comparative analysis of patients with positive expression of H-RAS showed that in the subgroups treated with arglabin and AC+arglabin, there was a statistically significant increase in relapse-free survival compared with the $A C$ subgroup: Kruskal-Wallis $=10.96$, where $p=0.004$. It was established that the positive expression of H-RAS negatively affects not only the direct effectiveness of neoadjuvant therapy but also worsens the rates of relapse-free survival. However, in patients with positive H-RAS expression who received arglabin in monotherapy, there was a statistically significant increase in relapse-free survival up to $16.5 \pm 1.1$ months compared with the standard AC regimen $(13.5 \pm 1.1$ months $)(p<0.05)$, the addition of arglabin to the standard AC regime also increased this indicator to $16.4 \pm 1.2$ months $(p<0.05)$.

CONCLUSION: These results may indicate the clinical applicability of determining H-RAS as a prognostic factor for relapse-free survival in breast cancer.

\section{Introduction}

The high heterogeneity of breast cancer is a prerequisite for a more in-depth study of the molecular mechanisms of functioning of malignant cells, the identification of factors affecting their growth rate, the ability to invasion and metastasis that affect the prognosis of the disease [1], [2], [3], [4], [5].

Studies of the relationship of H-RAS oncogene expression with the clinical and pathological parameters of breast cancer have demonstrated high expression of this oncogene in patients with an aggressive course of the disease and frequent metastasis [6], [7]. When comparing $\mathrm{H}-\mathrm{RAS}$ expression with the clinical and pathological parameters of breast cancer and gastric cancer, it was shown that high expression in patients with breast cancer is often associated with tumor aggressiveness [8], [9], [10]. Conducted studies have shown that the expression of H-RAS protein can be used as a marker for predicting the progression of breast cancer, as well as to stratify patients depending on the expression status and the risk of metastasis for pre-operative chemotherapy courses [11]

Blocking RAS signaling, inhibition of H-RAS in breast cancer is a rather promising direction in therapy. Significant efforts have been made to develop pharmacological agents that block RAS function [12], [13], [14], [15], [16].

The first phase of the QLNC120 study, a new inhibitor of estimated glomerular filtration rate (EGFR) and HER2 kinase (study registration: NCT01931943), in previously treated patients with HER2-positive breast cancer, showed that nine out of fifteen patients 
$(60 \%)$ had a mutation in H-RAS exon. Patients with the H-RAS mutation achieved higher disease progressionfree survival rates (24.9 vs. 12.9 weeks, $p=0.023$ ) against the background of QLNC120 application. $\mathrm{H}-\mathrm{RAS}$ mutation correlated with the antitumor activity of QLNC120 [17].

Farnesyltransferase inhibitors also block the growth of wild-type RAS breast cancer xenografts MCF-7, causing a cell-cycle block in the $\mathrm{G} 2 / \mathrm{M}$ or $\mathrm{Gl}$ phase and inducing apoptosis [18], [19]. Phase II of a clinical study of the combination of farnesyltransferase inhibitor tipifarnib+capecitabine combination in 63 patients with a breast cancer diagnosis, after progressing to therapy with anthracyclines and taxanes, showed an insignificant response rate of up to $10 \%$ and a median of a relapsefree period of 2.6 months and the median overall survival of 11.4 months. This combination was superior to capecitabine therapy in mono mode but inferior in toxic manifestations since $68 \%$ of patients required dose modification that was associated with tipifarnib [20].

The use of farnesyltransferase inhibitor arglabin during radiation therapy reduced the tumor volume by 5.5 times with intratumoral administration of the drug, by 8.5 times with intravenous administration, and in the comparison group, the tumor decreased only by 2.8 times. The use of arglabin significantly more often leads to pronounced radiation pathomorphism of the tumor, corresponding to the III-IV degree: With intratumoral administration in $64 \%$ of cases, with intravenous administration in $50 \%$, and with radiation treatment in $37 \%$. The intravenous administration of arglabin during radiation therapy has a positive effect on the long-term results of the complex treatment of patients with locally advanced breast cancer; the indicators of 2 and 3-year survivals were $93 \%$ and $90 \%$, respectively, which is significantly higher than when radiotherapy alone $(63 \%$ and $53 \%$, respectively) [21], [22].

Preclinical and clinical studies indicate that farnesyltransferase inhibitors are active in breast cancer with increased expression of the H-RAS oncogene. Thus, a study of the mechanism of the effect of these drugs on signaling pathways contributed to the identification of a new therapeutic target for the treatment of breast cancer, as well as improved rates of relapse-free survival.

The aim of this study was to study relapse-free survival depending on the expression of the H-RAS oncoprotein in patients who received different treatment regimens with a farnesyltransferase inhibitor.

\section{Materials and Methods}

The criteria for inclusion in the study were: Morphological samples of patients with histological verification, Stage II and III of the disease, T2N1-2M0, and T3NO-2MO. A group of 100 patients with a diagnosis of locally advanced breast cancer was recruited between January 2012 and February 2014. Their age ranged from 29 to 78 years, and the average age was 59 years (56 \pm 1.2$)$. The clinical-stage has been described based on the TNM International Classification of Malignant Tumors ( $7^{\text {th }}$ Edition). The study was approved by the Ethics Committee of the Medical University of Karaganda (Karaganda, Kazakhstan).

Immunohistochemical determination of the expression of $\mathrm{H}-\mathrm{RAS}$ oncoprotein was determined in samples of archival histological material of patients with breast cancer before treatment and after. Expression was evaluated independently by two researchers. A positive reaction was considered positive staining on the membrane and in the cytoplasm of tumor cells. The percentage of positively stained cells and staining intensity was evaluated. Positive cell percentage: $<10 \%-0$; 10-50\%-1; 51-80\%-2; >81\%-3. Reaction rate: lack of reaction - 0 points; weak reaction - 1 point; moderate reaction - 2 points; pronounced reaction -3 points. IRS rating scale: $0-2$ points - negative reaction; 3-4 points - weak reaction; 6-8 points - moderate reaction; 9-12 points - a high degree reaction. Coloring on the membrane and cytoplasm of tumor cells was considered a positive reaction. Patients with a positive reaction were included in the study group. As a negative immunophenotype was considered the expression of $\mathrm{H}-\mathrm{RAS}$ with an IRS point (0-2 points), in $\leq 20 \%$ of stained tumor cells. Patients with negative expression were included in the comparison group.

All patients received comprehensive treatment, including four courses of neoadjuvant drug therapy, surgical treatment in the amount of radical mastectomy, or radical sectoral resection of the breast. After evaluating the drug pathomorphism of the tumor, patients underwent four courses of adjuvant drug chemotherapy and radiation therapy, if indicated. In hormone-dependent cancer, adjuvant hormone therapy was performed.

A blind randomized study was conducted to select a neoadjuvant therapy regimen and assign it to treatment groups.

Drug therapy was carried out according to the following schemes:

Polychemotherapy according to scheme doxorubicin $60 \mathrm{mg} / \mathrm{m}^{2}$ and cyclophosphamide $600 \mathrm{mg} / \mathrm{m}^{2}$ intravenously on 1 day of every 21-day cycle.

Monotherapy with drug arglabin $370 \mathrm{mg} / \mathrm{m}^{2}$ from 1 to 7 days of every 21 day cycle was prescribed.

Drug therapy (chemotherapy according to the $\mathrm{AC}+$ arglabin regimen) doxorubicin $60 \mathrm{mg} / \mathrm{m}^{2}$, cyclophosphamide $600 \mathrm{mg} / \mathrm{m}^{2}$ intravenous 1 day, and arglabin $370 \mathrm{mg} / \mathrm{m}^{2}$ from 1 to 7 days of every 21-day cycle. 


\section{Statistical analysis}

For a comprehensive assessment of treatment results, a relapse-free survival analysis was used. In this work, we used the dynamic actuarial method for calculating the relapse-free survival, according to Kaplan-Meier using the "Statistica 10.0" program. An indicator of a statistically significant difference was the level $p<0.05$.

\section{Results and Discussion}

All 100 patients were women with an average age of 59 years $(56 \pm 1.2)$. The average follow-up period was 12 months. H-RAS expression was evaluated in 200 samples of tumor tissue before and after neoadjuvant breast cancer therapy. According to the classification criteria (Table 1), a total of 45 tumor samples $(45 \%)$ were positive for the expression of $\mathrm{H}$-RAS oncoproteins (on the IRS scale from 3 to 12 points) before treatment and 35 tumor samples (35\%) after treatment (Table 1).

Table 1: The level of expression of H-RAS depending on therapy

\begin{tabular}{llll}
\hline The expression level of H-RAS oncoprotein according to IRS scale $(\mathrm{n}=100)$ \\
\hline Therapy & $\begin{array}{l}\text { Strong expression } \\
(\mathrm{M} \pm \mathrm{SD})\end{array}$ & $\begin{array}{l}\text { Moderate expression } \\
(\mathrm{M} \pm \mathrm{SD})\end{array}$ & $\begin{array}{l}\text { Negative expression } \\
(\mathrm{M} \pm \mathrm{SD})\end{array}$ \\
\hline Before treatment & $32(78.4 \pm 8.7)$ & $13(43.0 \pm 6.4)$ & $55(13.50 \pm 5.2)$ \\
After treatment & $25(75.4 \pm 6.9)$ & $10(41.2 \pm 3.7)$ & $65(14.50 \pm 4.1)$ \\
\hline
\end{tabular}

A study of relapse-free survival showed that in the comparison group with negative expression of $\mathrm{H}$-RAS, the median relapse-free survival was $33.0 \pm 1.1$ months (Figure 1).

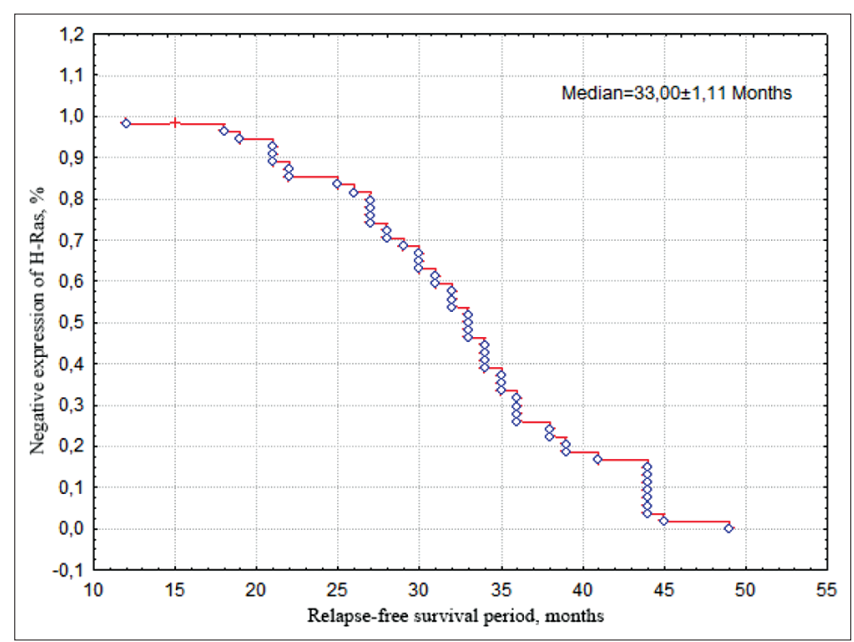

Figure 1: Relapse-free survival of patients diagnosed with breast cancer and negative expression of $\mathrm{H}$-Ras

A comparative analysis in patients with negative expression of $\mathrm{H}-\mathrm{RAS}$ oncoproteins showed a statistically significant increase in relapse-free survival in subgroups who received neoadjuvant chemotherapy according to the $\mathrm{AC}$ and $\mathrm{AC}+$ Arglabin regimen compared
Table 2: Relapse-free survival rates for patients diagnosed with breast cancer and negative expression of H-RAS who received neoadjuvant therapy

\begin{tabular}{ll}
\hline Subgroup of neoadjuvant drug therapy & Relapse-free survival \\
\hline AC $(n=23)$ & $33.0 \pm 5.19^{*}$ \\
AC+Arglabin $(n=18)$ & $34.0 \pm 5.4^{*}$ \\
Arglabin $(n=14)$ & $25.4 \pm 3.67$ \\
\hline${ }^{*}$ Reliability $p<0.05$ compared with Arglabin. &
\end{tabular}

with arglabin monotherapy: Kruskal-Wallis=12.56, where $p=0.001$ (Table 2 and Figure 2).

The use of arglabin in combination with the standard $A C$ regimen in patients with negative expression of $\mathrm{H}$-RAS did not improve relapse-free survival rates $(p=0.001)$.

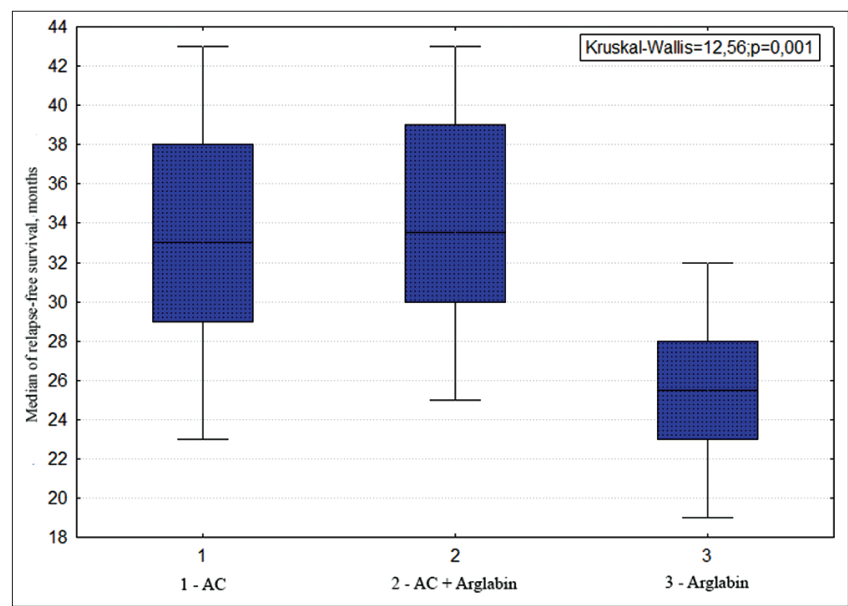

Figure 2: Comparative analysis of relapse-free survival in patients of the comparison group with negative expression of $\mathrm{H}$-Ras

The neoadjuvant therapy with arglabin in patients with negative expression of $\mathrm{H}-\mathrm{RAS}$ in terms of relapse-free survival was less effective compared to the standard $A C$ regimen.

Relapse-free survival in the study group of patients diagnosed with breast cancer and positive expression of H-RAS who received neoadjuvant drug therapy was $16.0 \pm 1.0$ months (Figure 3).

As can be seen in Figure 3, disease-free survival was $16.0 \pm 1.0$ months.

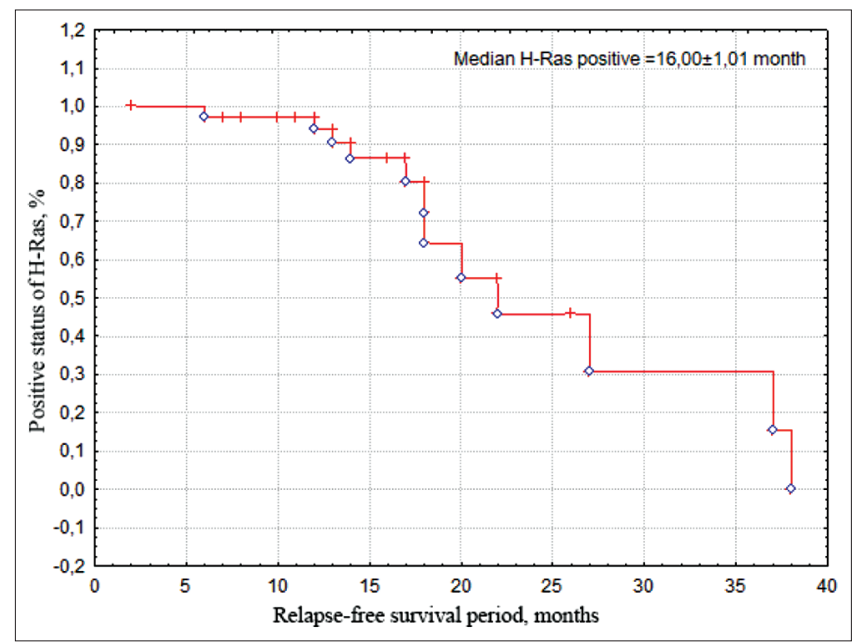

Figure 3: Relapse-free survival of patients diagnosed with breast cancer and positive expression of $\mathrm{H}$-Ras who received neoadjuvant drug therapy 
A comparative analysis in patients with positive expression of $\mathrm{H}-\mathrm{RAS}$ showed that in the subgroups of patients treated with Arglabin and $A C+$ Arglabin, there was a statistically significant increase in relapse-free survival compared with the AC subgroup: KruskalWallis $=10.96$, where $p=0.004$ (Table 3 and Figure 4).

Table 3: Relapse-free survival rates for breast cancer patients with positive H-RAS expression who received neoadjuvant therapy

\begin{tabular}{ll}
\hline Subgroup of neoadjuvant drug therapy & Relapse-free survival \\
\hline AC $(n=16)$ & $13.5 \pm 2.75^{*}$ \\
AC+Arglabin $(n=12)$ & $16.4 \pm 2.10^{*}$ \\
Arglabin $(n=17)$ & $16.5 \pm 2.03$ \\
\hline${ }^{*}$ Reliability $p<0.05$ compred with Arglabin
\end{tabular}

${ }^{*}$ Reliability $p<0.05$ compared with Arglabin.

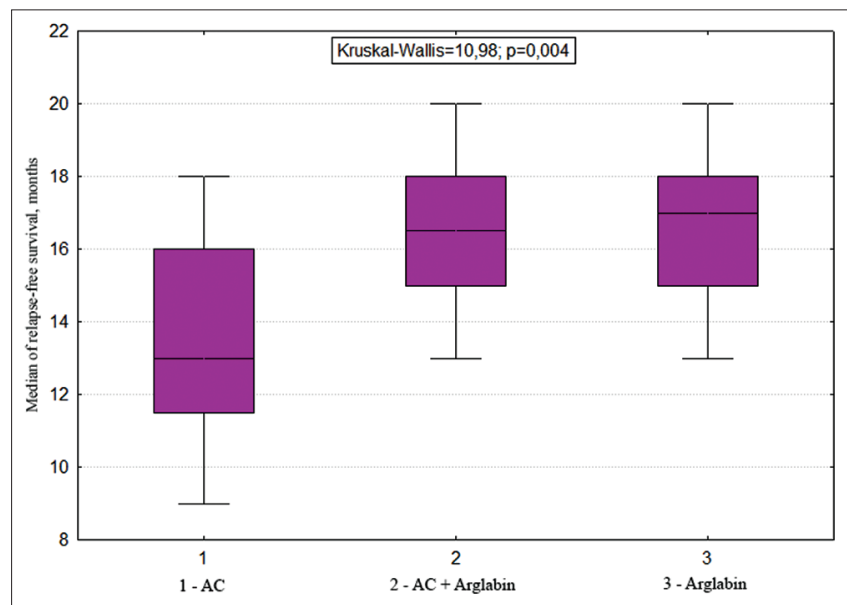

Figure 4: Comparative analysis of relapse-free survival in patients of the study group with positive expression of $\mathrm{H}$-Ras

A comparative analysis showed that in patients diagnosed with breast cancer and negative status of $\mathrm{H}-\mathrm{RAS}$, relapse-free survival rates were statistically higher than in patients with positive H-RAS, $p=0.001$, according to the Log-Rank Test (Figure 5).

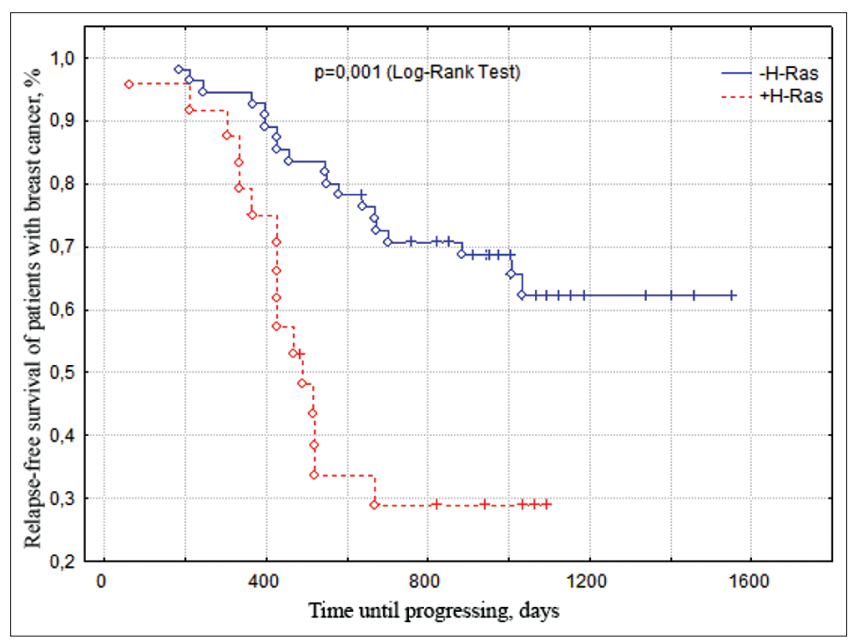

Figure 5: Relapse-free survival of patients with breast cancer who received neoadjuvant drug therapy

A comparative analysis of breast cancer patients who received neoadjuvant therapy is presented in Table 4 and Figure 6.

A comparative analysis of relapse-free survival indicators showed that in the comparison
Table 4: Relapse-free survival rates for patients diagnosed with breast cancer who received neoadjuvant therapy, depending on the treatment regimen

\begin{tabular}{lllll}
\hline Comparison group & & & Study group \\
\cline { 1 - 2 } \cline { 1 - 1 } Treatment regimen & $\begin{array}{l}\text { Relapse-free } \\
\text { survival }\end{array}$ & & Treatment regimen & $\begin{array}{l}\text { Relapse-free } \\
\text { survival }\end{array}$ \\
\hline AC $(n=23)$ & $33.0 \pm 5.19^{*}$ & & AC $(n=16)$ & $13.5 \pm 2.75^{*}$ \\
AC+Arglabin $(n=18)$ & $34.0 \pm 5.4^{*}$ & & AC+Arglabin $(n=12)$ & $16.4 \pm 2.10^{*}$ \\
Arglabin $(n=14)$ & $25.4 \pm 3.67$ & & Arglabin $(n=17)$ & $16.5 \pm 2.03$ \\
Total $(n=55)$ & $33.0 \pm 10.29^{*}$ & Total $(n=45)$ & $16.0 \pm 1.0^{*}$ \\
\hline${ }^{*}$ Reliability $p<0.01$ compared with the comparison group.
\end{tabular}

group the indicators were statistically significantly higher than in the study group: Mann-Whitney $U$ Test $=15.11 ; p=0.03$.

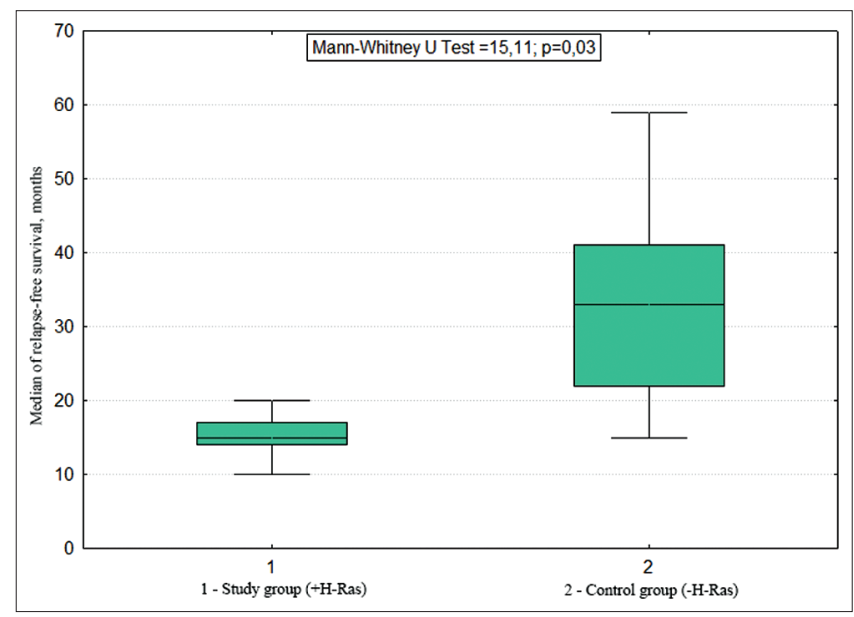

Figure 6: Comparative analysis of relapse-free survival of patients with breast cancer in the study groups

Subgroup comparative analysis also showed that in patients with negative expression of $\mathrm{H}$-RAS in all subgroups, regardless of the neoadjuvant therapy regimen, the rates of relapse-free survival were statistically higher than in the group with positive H-RAS expression.

It has also been established that positive expression of H-RAS worsens relapse-free survival indicators. However, in patients with positive H-RAS expression who received arglabin, there was a statistically significant increase in relapse-free survival up to $16.5 \pm 1.1$ months compared with the standard AC regimen (13.5 \pm 1.1 months) $(p=0.02)$, the use of arglabin in combination with the standard $A C$ regime also increased this indicator to $16.4 \pm 1.2$ months $(p<0.05)$.

\section{Discussion}

One of the most important issues in oncology over the years is the problem of predicting the course of malignant neoplasms to possibly predict the development of various forms of disease progression. In this regard, the search for additional markers to assess the risk of tumor recurrence remains relevant and today. The role of RAS genes in malignant tumors is 
multifaceted since they are involved in the proliferation of various tumor cells. Modern targeted therapy already has some success with RAS-associated colorectal cancer, melanoma, and pancreatic cancer [23]. For patients with breast cancer, studies on the role of RAS genes are ongoing, especially in the last few years.

Demetrios et al. conducted an immunohistochemical study of 75 cases of benign and malignant diseases of the mammary gland and determined the expression of p21 H-RAS protein. Most complex cystic diseases, hyperplastic fibroadenomas, and all types of breast carcinomas showed a high expression of $\mathrm{p} 21$. These results show that increased expression of p21 H-RAS may play an important role in the development of certain precancerous and malignant affections of mammae [24].

When studying the expression of H-RAS (p21ras - monoclonal antibody 235-1.7.1) in 297 patients with breast carcinoma, $58 \%$ of $\mathrm{H}$-RAS positive tumor cells were detected. It was also demonstrated that high expression of H-RAS oncoproteins (p21ras) correlated with the largest tumor tissue size, the presence of regional metastasis, and a high proliferative activity index $\mathrm{Ki}-67$, as well as tumors with negative hormonal status. The detection of positive expression of H-RAS (p21ras) was also associated with a more favorable prognosis in patients without metastases in regional lymph nodes [25].

The researchers also showed that the high frequency of expression of Ras and Her2neu proteins in breast cancer is associated with disease progression [26].

Numerous studies of H-RAS proteins in breast cancer have shown that these biological structures play an important role in the proliferation and progression of breast cancer [27], [28], [29].

However, to date, the role of H-RAS expression in breast cancer has not been fully studied, and thus its further study is an urgent problem.

In our study, it was demonstrated that positive H-RAS expression worsens relapse-free survival indicators in patients with breast cancer compared with a group of patients with negative H-RAS status. It was found that in patients with positive H-RAS H-RAS expression who received drug "Arglabin," a statistically significant increase in relapse-free survival was observed up to $16.5 \pm 1.1$ months compared with the standard $A C$ regimen $(13.5 \pm 1.1$ months), where $p<0.05$. The combination of arglabin + standard $A C$ regime also increased this indicator to $16.4 \pm 1.2$ months $(p<0.05)$.

\section{References}

1. Wright KL, Adams JR, Liu JC, Loch AJ, Wong RG, Jo CE, et al. Ras signaling is a key determinant for metastatic dissemination and poor survival of luminal breast cancer patients. Cancer Res. 2015;75(22):4960-72. https://doi.org/10.1158/0008-5472. can-14-2992

PMid:26400062

2. Haddad TC, Goetz MP. Landscape of neoadjuvant therapy for breast cancer. Ann Surg Oncol. 2015;22(5):1408-15. https://doi. org/10.1245/s10434-015-4405-7

PMid:25727557

3. King TA, Morrow M. Surgical issues in patients with breast cancer receiving neoadjuvant chemotherapy. Nat Rev Clin Oncol. 2015;12(6):335-43. https://doi.org/10.1038/nrclinonc.2015.63 PMid:25850554

4. Nurgaziev KS, Toleutaiuly K, Baipeisov DM, Ospanov SE Development of cancer care in the republic of Kazakhstan. Young Sci. 2017;19:4-5.

5. OECD. Health of the Population of the Republic of Kazakhstan and the Activities of Healthcare Organizations in 2018, Stats Zhynak Astana. Paris, France: OECD; 2018. p. 338-42.

6. Eckert LB, Repasky GA, Ulku AS, McFall A, Zhou H, Sartor Cl, et al. Involvement of ras activation in human breast cancer cell signaling, invasion, and anoikis. Cancer Res. 2004;64(13):458592. https://doi.org/10.1158/0008-5472.can-04-0396 PMid:15231670

7. Baum JE, Sung KJ, Tran H, Song W, Ginter PS. Mammary epithelial-myoepithelial carcinoma: Report of a case with HRAS and PIK3CA mutations by next-generation sequencing. Int J Surg Pathol. 2019;27(4):441-5. https://doi. org/10.1177/1066896918821182

PMid:30585117

8. Cree IA. Progress and potential of RAS mutation detection for diagnostics and companion diagnostics. Expert Rev Mol Diagn. 2016;16(10):1067-72. https://doi.org/10.1080/14737159.2016.1 221345

PMid:27494709

9. Pylayeva-Gupta Y. RAS oncogenes: Weaving a tumorigenic web. Nat Rev Cancer. 2011;11(11):761-74. https://doi. org/10.1038/nrc3106

PMid:21993244

10. Bonnot E, Passot G. RAS mutation: Site of disease and recurrence pattern in colorectal cancer. Chin Clin Oncol. 2019;8(5):55. https://doi.org/10.21037/cco.2019.08.11 PMid:31597436

11. Spandidos DA, Karaiossifidi $H$, Malliri A, Linardopoulos $S$, Vassilaros $\mathrm{S}$, Tsikkinis $\mathrm{A}$, et al. Expression of ras $\mathrm{Rb} 1$ and p53 proteins in human breast cancer. Anticancer Res. 1992;12(1):81-9.

PMid:1567185

12. Kazi A, Xiang S, Yang $H$, Chen L, Kennedy $P$, Ayaz M, et al Dual farnesyl and geranylgeranyl transferase inhibitor thwarts mutant KRAS-driven patient-derived pancreatic tumors. Clin Cancer Res. 2019;25:5984-96. https://doi.org/10.1158/10780432.ccr-18-3399

13. Lee $\mathrm{KH}$, Koh M, Moon A. Farnesyl transferase inhibitor FTI277 inhibits breast cell invasion and migration by blocking H-ras activation. Oncol Lett. 2016;12(3):2222-6. https://doi. org/10.3892/ol.2016.4837

PMid:27602167

14. Cox AD, Der CJ, Philips MR. Targeting RAS membrane association: Back to the future for anti-RAS drug discovery. Clin Cancer Res. 2015;21(8):1819-27. https://doi.org/10.1158/10780432.ccr-14-3214 PMid:25878363

15. Koh MS, Moon A. Activation of H-ras and Rac1 correlates with epidermal growth factor-induced invasion in Hs578T 
and MDA-MB-231 breast carcinoma cells. Biochem Biophys Res Commun. 2011;406(1):25-9. https://doi.org/10.1016/j. bbrc.2011.01.092

16. Arteaga $\mathrm{CL}$, Sliwkowski $\mathrm{MX}$, Osborne $\mathrm{CK}$, Perez $\mathrm{EA}$ Puglisi F, Gianni L. Treatment of HER2-positive breast cancer: Current status and future perspectives. Nat Rev Clin Oncol. 2012;9(1):16-32.

PMid:22124364

17. Zhang T, Li Q, Chen I, Luo Y, Fan Y, Xu B. Phase I study of QLNC120, a novel EGFR and HER2 kinase inhibitor, in pre-treated patients with HER2-overexpressing advanced breast cancer. Oncotarget. 2017;8(22):36750-60. https://doi. org/10.18632/oncotarget.13581

PMid:27902470

18. Yerushalmi R, Woods R, Ravdin PM, Hayes MM, Gelmon KA Ki67 in breast cancer: Prognostic and predictive potential. Lancet Oncol. 2010;11(2):174-83. https://doi.org/10.1016/ s1470-2045(09)70262-1

PMid:20152769

19. Yoshioka T, Hosoda M, Yamamoto M, Taguchi K, Hatanaka KC, Takakuwa $\mathrm{E}$, et al. Prognostic significance of pathologic complete response and Ki67 expression after neoadjuvant chemotherapy in breast cancer. Breast Cancer. 2013;22(2):18591. https://doi.org/10.1007/s12282-013-0474-2 PMid:23645542

20. Shaikenov TE, Adekenov SM, Basset S, Trivedy M, Wolfinbarger L. Arglabin is a Novel Inhibitor of the Farnesylation of Ras Proteins. Kazakhstan: Reports of Ministry of Science, Academy of Sciences Republic of Kazakhstan; 1998. p. 64-75.

21. Zhumakayeva A, Rakhimov K, Sirota V, Arystan L, Madiyarov A, Adekenov S. Long-term results of combination therapy for locally advanced breast cancer. Georgian Med News. 2018;282:30-5. PMid:30358536

22. Zhumakayeva AM, Rakhimov KD, Omarova IM, Arystan LI, Adekenov SM. Experimental, clinical and morphological analysis of $\mathrm{H}$-ras oncoproteins for locally advanced breast cancer. Open Access Maced J Med Sci. 2019;7(19):3153-7. https://doi.org/10.3889/oamjms.2019.708

PMid:31949508

23. Murugan AK, Grieco $M$, Tsuchida N. RAS mutations in human cancers: Roles in precision medicine. Semin Cancer Biol. 2019;59:23-35. https://doi.org/10.1016/j. semcancer.2019.06.007 PMid:31255772

24. Spandidos DA, Agnantis NJ. Human malignant tumors of the breast, as compared to their respective normal tissue, have elevated of the Harvey ras oncogene. Anticancer Res. 1984;4(4-5):269-72.

PMid:6207764

25. Sharif S, Moran A, Huson SM, Iddenden R, Shenton A, Howard $\mathrm{E}$, et al. Women with neurofibromatosis 1 are at a moderately increased risk of developing breast cancer and should be considered for early screening. J Med Genet. 2007;44(8):481-4. https://doi.org/10.1136/jmg.2007.049346 PMid:17369502

26. von Lintig FC, Dreilinger $A D$, Varki NM, Wallace $A M$, Casteel DE, Boss GR. Ras activation in human breast cancer. Breast Cancer Res Treat. 2000;62(1):51-62. https://doi. org/10.1023/a:1006491619920 PMid:10989985

27. Kai K, Iwamoto T, Kobayashi T. Ink4a/Arf(-/-) and HRAS(G12V) transform mouse mammary cells into triple-negative breast cancer containing tumorigenic CD49f $(-)$ quiescent cells. Oncogene. 2014;33(4):440-8. https://doi.org/10.1038/ onc.2012.609 PMid:23376849

28. Jiang BH, Liu LZ. PI3K/PTEN signaling in angiogenesis and tumorigenesis. Adv Cancer Res. 2009;102:19-65.

PMid:19595306

29. Karnoub AE, Weinberg RA. Ras oncogenes: Split personalities. Nat Rev Mol Cell Biol. 2008;9(7):517-31. https://doi.org/10.1038/ nrm2438

PMid:18568040 